\title{
The Growth of Different Probiotic Microorganisms in Soymilk from Different Soybean Varieties and their Effects on Anti-oxidant Activity and Oligosaccharide Content
}

\author{
Marguerite Niyibituronsa ${ }^{1,2,3}$, Arnold N. Onyango ${ }^{2}$, Svetlana Gaidashova ${ }^{1}$, Samuel Imathiu ${ }^{2}$, Marthe De Boevre ${ }^{3}$, \\ Diederik Leenknecht ${ }^{3}$, Ellen Neirnck ${ }^{3}$, Sarah De Saeger ${ }^{3}$, Pieter Vermeir ${ }^{3} \&$ Katleen Raes $^{3}$ \\ ${ }^{1}$ Rwanda Agriculture Board, Kigali, Rwanda \\ ${ }^{2}$ Jomo Kenyatta University of Agriculture and Technology, Nairobi, Kenya \\ ${ }^{3}$ Ghent University, Gent and Kortrijk, Belgium \\ Correspondence: Marguerite Niyibituronsa, Rwanda Agriculture Board, Rwanda, P.O.BOX 5016 Kigali, Rwanda. \\ Tel: 250-788-848-200. E-mail: niyibituronsam@gmail.com
}

Received: December 2, 2018

Accepted: December 18, 2018 Online Published: January 12, 2018

doi:10.5539/jfr.v8n1p41

URL: https://doi.org/10.5539/jfr.v8n1p41

\begin{abstract}
Soymilk is a good source of proteins and health-promoting isoflavones, but it contains oligosaccharides that cause flatulence. Fermenting it with probiotic bacteria may reduce the oligosaccharides and enhance its health benefits.The present study determined the growth of different lactic acid bacteria (LAB) in soymilk obtained from soybean varieties grown in Rwanda and the effect of fermentation on oligosaccharides that cause flatulence (stachyose, raffinose and verbascose), and antioxidant activity of fermented soybean milk. After fermentation at $30^{\circ} \mathrm{C}$ for 24 hours, Lactobacillus plantarum, Lactobacillus acidophilus, Lactobacillus brevis, Lactobacillus reuteri, Lactobacillus rhamnosus, Lactococcus cremoris and Lactobacillus casei attained around $8 \log \mathrm{CFU} / \mathrm{ml}$, which is sufficient for probiotic effects. However, only L. reuteri, L. brevis and L. plantarum caused sufficient drop in $\mathrm{pH}$ and increase in viscosity characteristic of a good fermented product. Soymilk from different soybean varieties did not show significant differences in the growth of these three LAB.These LAB reduced content of oligosaccharides and total polyphenols, but increased antioxidant activity in soymilk, which translate into health benefits of fermented soybean products.
\end{abstract}

Keywords: fermentation, lactic acid bacteria, polyphenols, raffinose, Rwanda

\section{Introduction}

Soybean (Glycine max L) is grown worldwide for food consumption mainly because of its high nutritional quality, especially in terms of proteins and isoflavones (Gandhi, 2009; Mudryj, Aukema, \& Yu, 2015). Soybean products are appreciated due to their health benefits (Riciputi et al., 2016). Soymilk is cholesterol free and is thus suitable for patients with cardiovascular problems (Vij, Hati, \& Yadav, 2011). It contains phenolic substances which are powerful antioxidants (Yao, Xiao-Nan, \& Dong, 2010). Soymilk can be a substitute of cow's milk for lactose intolerant people.This nutritious beverage is of interest as a weaning food to reduce malnutrition. However, it has a green odor which reduces its palatability (Khaleque, Bannatyne, \& Wallace, 1970; Kumari et al., 2015; Min, Yu, Yoo, \& Martin, 2005; Yu, Liu, Hu, \& Xu, 2017). The beany flavour caused by lipoxygenase activity, and lowering acceptability of soymilk, may be reduced by fermentation (Y. J. Cheng, Thompson, \& Brittin, 1990; Peng \& Guo, 2015; Wang, Kraidej, \& Hesseltine, 1974). Fermentation also lowers the content of the oligosaccharides, namely verbascose, stachyose and raffinose, which cause flatulence (Battistini et al., 2018; Gote, Umalkar, Khan, \& Khire, 2004; Kaczmarska, Chandra-Hioe, Zabaras, Frank, \& Arcot, 2017). Fermented soymilk is easily digestible and has antioxidant properties that prevent cancer (Jooyandeh, 2011; Takagi, Kano, \& Kaga, 2015; Telang, Joshi, Sutar, \& Thorat, 2010; Vij et al., 2011; Ziaei \& Halaby, 2017). This may be due to the improvement in $\beta$-galactosidase activity converting isoflavone glycosides towards aglycones, the latter are the bioactive forms known for their health benefits (Liu, Yang, \& Fang, 2018; Otieno, Ashton, \& Shah, 2006; Tsangalis, Ashton, Stojanovska, Wilcox, \& Shah, 2004; Villares, Rostagno, García-Lafuente, Guillamón, \& Martínez, 2011). A study done previously reported stronger antioxidant activity by isoflavones extract from fermented soybean milk than from the unfermented one (Marazza, Nazareno, Savoy, Giori, \& Garro, 2012). 
Fermentation also improves the texture and could have some protective effects against intestinal infections (I.-C. Cheng, 2005; Shurtleff \& Aoyagi, 2004).

Some of the probiotic strains that can grow in soymilk include L. casei Zhang, Bifidobacterium animalis ssp. lactis V9, L. acidophilus NCFM, L. rhamnosus GG, Bifidobacterium animalis Bb12, and L. Casei Shirota at $37^{\circ} \mathrm{C}$ (Li, Yan, Wang, \& Zhang, 2012). A study done by Mishra (2013) showed that the combination of $L$. acidophilus-L. plantarum was the best, counting more than $9 \log$ CFU/ml (Mishra \& Mishra, 2013). Lactic acid bacteria enhance the bioavailability of isoflavones due to their beta-galactosidase activity converting the glucoside forms into aglycones which have the bioactive properties (Chien, Yang, \& Chou, 2013; Horackova, Muhlhansova, Slukova, Schulzova, \& Plockova, 2015; Malashree et al., 2016). Strains have different optimal growth conditions depending on the characteristics of the organism and the culture substrate (Bansal, Mangal, Sharma, Yadav, \& Gupta, 2015; Breed, Murray, \& Hitchens, 1948).

The objectives of the present study were to determine the growth of different lactic acid bacteria in soymilk, and their effects on soymilk oligosaccharides, phenolic compounds including isoflavones, and the antioxidant activity of the fermented soymilk.

\section{Materials and Methods}

\subsection{Soybeans}

Eight samples of dried soybean grains were collected including 5 known varieties from the Rwanda Agriculture Board stores (Peka6 (P6), SC. Sequel (Sequel), SC. Squire (Squire), SB24 (SB) and SC. Saga (Saga)) and 3 unknown local varieties grown by farmers in East (LocE), South (LocS) and West Province (LocW) of Rwanda.

\subsection{Soymilk Preparation}

Soymilk was prepared by the method of Hosken (Hosken, 2000) that was shown to give good nutrient extraction (Niyibituronsa et al., 2018). Soybean grains were cleaned by hand removing dirt and damaged soybeans. The grains were soaked for 16 hours $\left(1 / 4\right.$; soybean/water; w/v) at room temperature $\left(22^{\circ} \mathrm{C}\right)$. The soaking water was drained and the soybeans were washed with cold water. The soybeans were blended, after mixing with water (ratio $1 / 8, w / v$ ), followed by filtration through a cheese cloth. The soymilk was heated until boiling, and then further cooled to the inoculation temperature of $30^{\circ} \mathrm{C}$.

\subsection{Inocula Preparation}

Stock culture of seven lactic acid bacteria: Lactobacillus plantarum (93), Lactobacillus acidophilus (88), Lactobacillus brevis (89), Lactobacillus reuteri (94), Lactobacillus rhamnosus LMG 25859, Lactococcus cremoris SK11and Lactobacillus casei (shirota), were obtained from the Belgian Coordinated Collections of Microorganisms-Laboratory of Microbiology: BCCM-LMG (Ghent, Belgium), a bacterial culture collection currently comprising over 25.000 well-characterized strains (More details can be found on BCCM/LMG website). For each bacterium, a mother culture was prepared by adding $0.1 \mathrm{ml}$ stock culture (stored in glycerol at $-18^{\circ} \mathrm{C}$ ) to $10 \mathrm{ml}$ sterile medium (MRS). From the mother culture, inocula were prepared by adding $0.1 \mathrm{ml}$ mother culture into fresh MRS medium. Tubes were incubated for $18 \mathrm{~h}$ at $30^{\circ} \mathrm{C}$. The $\mathrm{CFU} / \mathrm{ml}$ of the inocula was measured by plating the appropriate dilutions (made in $0.9 \% \mathrm{NaCl}$ ) on MRS agar plates. Plates were incubated at $30^{\circ} \mathrm{C}$ for $24 \mathrm{~h}$.

\subsection{Fermentation of Soymilk: Screening Experiment}

Soymilk (20ml) prepared from soybeans (kindly received from Alpro, Wevelgem, Belgium) was inoculated with $5.10^{6} \mathrm{CFU}$ of the 7 different lactic acid bacteria. The flasks were then incubated for $24 \mathrm{~h}$ at $30^{\circ} \mathrm{C}$. At several time points during $24 \mathrm{~h}, \mathrm{pH}$ was measured to follow the acidification profile during fermentation. Subjective inspection of the change in viscosity was done by scoring it as 1,2 and 3 for high viscosity, medium viscosity and low viscosity respectively. After $24 \mathrm{~h}$ incubation, the appropriate dilutions of the fermented soymilk was plated out on MRS agar plates for counting the CFU/ml. Plates were incubated at $30^{\circ} \mathrm{C}$ for $24 \mathrm{~h}$.

\subsection{Production of fermented Soymilk from different Soybean Varieties Using Three Selected Lactic Acid Bacteria}

Based on the results of the screening experiment, 3 strains, namely L. plantarum, L. brevis and L. reuteri were selected to ferment soymilk from 8 different soybean varieties of Rwanda. To $60 \mathrm{ml}$ of soymilk, $3 \mathrm{ml}$ inoculum $\left(10^{6} \mathrm{CFU} / \mathrm{ml}\right)$ was added. Incubation was done at $30^{\circ} \mathrm{C}$ for $24 \mathrm{~h}$. Subjective inspection of the change in viscosity was done. The $\mathrm{pH}$ was measured at $\mathrm{t}=0$ and $\mathrm{t}=24 \mathrm{~h}$. Titratable acidity was determined after $24 \mathrm{~h}$ and expressed as g lactic acid/l (g LA/l). Total count numbers were determined by plating. Soymilk samples ( 0 and $24 \mathrm{~h}$ fermentation) were also stored at $-20^{\circ} \mathrm{C}$ for further analysis of total phenolic compounds, antioxidant activity and oligosaccharide content. 


\subsection{Total Phenolic Compounds Extraction}

Phenolic compounds were extracted from $2.5 \mathrm{~g}$ of soymilk or from $0.5 \mathrm{~g}$ of soybean flour using $15 \mathrm{ml}$ of methanol (100\%). After homogenization for $45 \mathrm{~s}$ at $1000 \mathrm{rpm}$ using an Ultraturax, tubes were kept on ice for 15 minutes, and then centrifuged for 15 minutes at $4000 \mathrm{rpm}$ at $4{ }^{\circ} \mathrm{C}$. The supernatant was filtered into a $25 \mathrm{ml}$ volumetric flask using Whatman No.2 filter paper. Methanol $80 \%(10 \mathrm{ml})$ was added to the residues, mixed with an ultraturax for $20 \mathrm{~s}$ at $1000 \mathrm{rpm}$, centrifuged and filtered as previously. The flask was topped up to $25 \mathrm{ml}$ by $80 \%$ methanol (Shumoy, Gabaza, Vandevelde, \& Raes, 2017; Singleton, Orthofer, \& Lamuela-Raventós, 1999). The extract was kept for further analysis of total phenolic compounds and antioxidant activity.

\subsection{Total phenolic Compound Content (TPC) Using Folin Ciocalteu Phenol Reagent}

Some of the reagents used were $20 \% \mathrm{Na}_{2} \mathrm{CO}_{3}$, Folin Ciocalteu reagent (FC), $90 \%$ methanol. A gallic acid stock solution $(400 \mathrm{mg} / \mathrm{l})$ was prepared, of which several standard solutions were made between 0 and $50 \mathrm{mg} / \mathrm{l}$. Stock solution and dilutions were made in $90 \%$ methanol.

To each test tube, $1 \mathrm{ml}$ of standard or $1 \mathrm{ml}$ of sample extract was added. As a blank $1 \mathrm{ml} 90 \%$ methanol was used. FC $(0.5 \mathrm{ml})$ was added and, vortex, and incubated for $6 \mathrm{~min}$, followed by the addition of $1.5 \mathrm{~mL}$ $\mathrm{Na}_{2} \mathrm{CO}_{3}$-solution and $1 \mathrm{~mL}$ bi distilled water. After vortexing, test tubes were kept in the dark for 2 hours. Absorbance was measured using a spectrometer (Thermo Spectronic, GENESYS 20, Cambridge, England) at $760 \mathrm{~nm}$. The quantification was done against a standard curve of gallic acid. Results were expressed in terms of $\mathrm{mg}$ gallic acid equivalents per $100 \mathrm{~g}(\mathrm{mg} \mathrm{GAE} / 100 \mathrm{~g})$.

\subsection{Determination of Antioxidant (Free Radical Scavenging) Activity Using 1, 1-diphenyl-2-picrylhydrazyl} (DPPH)

The scavenging activity of samples was determined by adding $4 \mathrm{ml}$ DPPH $(0.1 \mathrm{mM})$ into $200 \mu \mathrm{L}$ methanolic extracts or into $200 \mu \mathrm{l}$ trolox standards $(0.01,0.02,0.04,0.08$ and $0.1 \mathrm{mg} / \mathrm{L})$ and a blank $(\mathrm{MeOH} 90 \%)$ (Kumaran\& Karunakaran, 2006; Shumoy et al., 2017). After vortexing, the test tubes were kept in the dark for 30 min. Absorbance was read using a spectrometer at $517 \mathrm{~nm}$ and results were expressed in terms of $\mathrm{mg}$ trolox equivalents per 100g.

\subsection{Oligosaccharides}

Raffinose, stachyose and verbascose were measured by the raffinose/D-galactose kit from Megazyme (Megazyme International Ireland, 2014). All of the reagents and filters were purchased from VWR chemicals, Leuven, Belgium. Prior to analysis, samples were clarified using carrez solutions. Therefore, $5 \mathrm{ml}$ of fermented and non-fermented soybean milk or $1 \mathrm{~g}$ of soybean flour were pipetted in a $100 \mathrm{ml}$ volumetric flask containing $60 \mathrm{ml}$ of water and mixed thoroughly. Then, $5 \mathrm{ml}$ of Carrez I, $5 \mathrm{ml}$ of Carrez II, and $10 \mathrm{ml}$ of $\mathrm{NaOH}$ were added, mixed and the volumetric flask was filled up with water to the mark. The filtration was done with a Whatman filter $\mathrm{N}^{0} 2$ to get a clear solution for use in the Megazyme assay. Each sample was measured using a UV-VIS called UV1 (from Thermo Spectronic Cambridge, England) for the combined raffinose and the free D-galactose which was subtracted at the end of the analysis.

\section{Data analysis}

SPSS 22 was used for the statistical analysis of the data. The comparison of means, ANOVA was done and the difference was considered significant at $\mathrm{P}$-value $<0.05$. Means were separated using least significance difference (LSD) post hoc tests.

\section{Results and Discussion}

\subsection{Screening Experiment}

The first screening of seven lactic acid bacteria used to ferment soybean milk at $30^{\circ} \mathrm{C}$ showed that most of the strains could grow well in soymilk (Table 1). 
Table 1. Screening of the growth (log CFU/ml soymilk) of seven lactic acid bacteria in soymilk

\begin{tabular}{lllllll}
\hline Lactobacillus & $\begin{array}{l}\text { Mean log CFU/ml } \\
\text { FSM at 0h }\end{array}$ & SD & $\begin{array}{l}\text { Mean log CFU/ml } \\
\text { FSM at 24h }\end{array}$ & SD & Real growth & SD \\
\hline Brevis & 6.24 & 0.10 & 8.88 & 0.06 & 2.64 & 0.03 \\
Plantarum & 6.33 & 0.04 & 9.02 & 0.07 & 2.69 & 0.11 \\
Reuteri & 5.90 & 0.06 & 8.92 & 0.00 & $3.02^{*}$ & 0.06 \\
Cremoris & 5.88 & 0.00 & 8.59 & 0.12 & 2.71 & 0.11 \\
Casei & 5.84 & 0.06 & 8.28 & 0.44 & 2.44 & 0.50 \\
Acidophilus & 6.38 & 0.04 & 7.94 & 0.07 & 1.56 & 0.11 \\
Rhamnosus & 6.10 & 0.11 & 8.38 & 0.19 & 2.28 & 0.30 \\
\hline
\end{tabular}

*Significant real growth in soybean milk; CFU = colony forming unit, FSM = Fermented soybean milk, SD = standard deviation

The mean $\log \mathrm{CFU} / \mathrm{ml}$ in soymilk after 24 hours of fermentation ranged from 7.94 (L. acidophilus) to 9.02 ( $L$. plantarum), showing that $L$. acidophilus had the lowest growth in soymilk. For most of these bacteria, the logs $\mathrm{CFU} / \mathrm{ml}$ at 24 hours were higher than the $8 \log \mathrm{CFU} / \mathrm{ml}$ recommended for health benefit (Champagne, Raymond, Guertin, Martoni, \& Jones, 2016; Donkor, Henriksson, Vasiljevic, \& Shah, 2007). The real growth of lactic acid bacteria in FSM $(\log \mathrm{CFU} / \mathrm{ml}$ at $24 \mathrm{~h}-\log \mathrm{CFU} / \mathrm{ml}$ at $0 \mathrm{~h})$ was significantly higher for L. reuteri $(\mathrm{P}<0.05)$ followed by L. cremoris, $L$. plantarum and $L$. brevis.

Despite the high CFU levels attained by all the seven bacteria studied, only 3 strains gave good results for $\mathrm{pH}$ and viscosity after 24 hours of incubation. The soymilk fermented with L. plantarum, L. brevis and L. reuteri had a pH of 4.70, 4.78 and 4.73, respectively, after $24 \mathrm{~h}$ incubation, and all showed high viscosity. This is consistent with previous studies where a $\mathrm{pH}$ of 5 was reported after $24 \mathrm{~h}$ of soymilk fermentation with mixed cultures (Garro, de Valdez, \& de Giori, 2004). The viscosity was high, thus creamy fermented soymilk was made. For other strains i.e. L. cremoris, L. casei, L. acidophilus and L. rhamnosus the $\mathrm{pH}$ did not change significantly from time $0(\mathrm{pH}=6.6)$ to time $24 \mathrm{~h}(\mathrm{pH}=6.2)$, and the viscosity remained low. Molina et al. (2012) reported that soymilk fermented with $L$. reuteri for 6 hours attained a fairly high population of $1.6 \times 10^{7} \mathrm{CFU} / \mathrm{ml}$ but without much acidification ( $\mathrm{pH}$ of 6.8). In a previous study, L acidophilus at $\log 8.73 \mathrm{CFU} / \mathrm{ml}$ in soymilk gave a $\mathrm{pH}$ of $4.8, \log 8.98 \mathrm{CFU} / \mathrm{ml}$ in soymilk-apple juice blend (85:15) gave a pH of 3.83, while log 9.08 in soymilk-apple juice blend (75:25) gave a $\mathrm{pH}$ of 4.18 (Icier et al, 2015) showing that a higher CFU/ml does not necessarily translate into lower $\mathrm{pH}$.

\subsection{Soymilk Fermentation with L. plantarum, L. reuteri and L. brevis}

\subsubsection{Growth of the Lactic Acid Bacteria in Soymilk from 8 Varieties}

The three selected lactic acid bacteria L. plantarum, L. reuteri and L. brevis were used to ferment soybean milk from the 8 varieties grown in Rwanda. Table 2 summarizes the growth of the three strains in soymilk from the eight soybean varieties in a period of 24 hours. The final population ranged between 8.85 and $9.08 \log \mathrm{CFU} / \mathrm{ml}$. The mean final population after $24 \mathrm{~h}$ was $9.03,8.99$ and $8.98 \log \mathrm{CFU} / \mathrm{mL}$ for $L$. plantarum, $L$. reuteri and $L$. brevis respectively. The real growth of $L$. reuteri in all varieties of fermented soybean milk was significantly higher than L. plantarum and L. brevis $(\mathrm{P}<0.05)$. 
Table 2. The growth $\log$ CFU/ml soymilk) of Lactobacillus strains for soymilk from 8 soybean varieties

\begin{tabular}{llllllll}
\hline Varieties & Lactobacillus & $\begin{array}{l}\text { Mean log } \\
\text { CFU/ml 0h }\end{array}$ & SD & $\begin{array}{l}\text { Mean log } \\
\text { CFU/ml 24h }\end{array}$ & SD & $\begin{array}{l}\text { Real growth log } \\
\text { CFU/ml }\end{array}$ & SD \\
\hline Peka 6 & Plantarum & 6.41 & 0.11 & 9.01 & 0.13 & 2.61 & 0.14 \\
Saga & Plantarum & 6.33 & 0.17 & 9.00 & 0.02 & 2.67 & 0.18 \\
LocS & Plantarum & 6.45 & 0.06 & 9.05 & 0.00 & 2.60 & 0.06 \\
Squire & Plantarum & 6.34 & 0.14 & 9.00 & 0.03 & 2.67 & 0.11 \\
SB & Plantarum & 6.40 & 0.10 & 9.10 & 0.10 & 2.70 & 0.06 \\
Sequel & Plantarum & 6.44 & 0.05 & 9.10 & 0.06 & 2.66 & 0.03 \\
LocE & Plantarum & 6.32 & 0.16 & 9.08 & 0.09 & 2.76 & 0.08 \\
LocW & Plantarum & 6.36 & 0.16 & 8.94 & 0.06 & 2.58 & 0.13 \\
Peka 6 & Reuteri & 5.96 & 0.19 & 8.85 & 0.07 & $2.89^{*}$ & 0.25 \\
Saga & Reuteri & 5.93 & 0.21 & 8.89 & 0.07 & $2.95^{*}$ & 0.28 \\
LocS & Reuteri & 6.24 & 0.28 & 9.24 & 0.52 & $3.00^{*}$ & 0.24 \\
Squire & Reuteri & 5.99 & 0.20 & 8.91 & 0.05 & $2.92^{*}$ & 0.15 \\
SB & Reuteri & 5.89 & 0.07 & 8.99 & 0.12 & $3.10^{*}$ & 0.05 \\
Sequel & Reuteri & 5.94 & 0.09 & 9.13 & 0.08 & $3.19^{*}$ & 0.14 \\
LocE & Reuteri & 5.83 & 0.05 & 8.98 & 0.02 & $3.15^{*}$ & 0.04 \\
LocW & Reuteri & 5.92 & 0.13 & 8.90 & 0.02 & $2.98^{*}$ & 0.15 \\
Peka 6 & Brevis & 6.18 & 0.34 & 8.99 & 0.10 & $2.81^{*}$ & 0.24 \\
Saga & Brevis & 6.44 & 0.04 & 8.98 & 0.02 & 2.54 & 0.01 \\
LocS & Brevis & 6.28 & 0.26 & 9.00 & 0.16 & 2.72 & 0.12 \\
Squire & Brevis & 6.41 & 0.01 & 8.88 & 0.06 & 2.48 & 0.04 \\
SB & Brevis & 6.14 & 0.28 & 9.04 & 0.04 & 2.90 & 0.32 \\
Sequel & Brevis & 6.13 & 0.26 & 9.14 & 0.09 & 3.02 & 0.19 \\
LocE & Brevis & 6.40 & 0.00 & 8.98 & 0.15 & 2.58 & 0.15 \\
LocW & Brevis & 6.41 & 0.01 & 8.86 & 0.10 & 2.44 & 0.11 \\
\hline
\end{tabular}

*The real growth using Lactobacillus reuteri is significantly different from Lactobacillus

Plantarum and Lactobacillus brevis. SD =Standard deviation

L. reuteri can be promoted not only for fermentation of soybean milk but also for its health benefit as vitamin B-12 producer in the body (Molina, Medici, Font De Valdez, \& Taranto, 2012). Among other benefits, $L$. plantarum metabolizes cholesterol and may reduce the risk for cardiovascular disease (Amutha \& Kokila, 2015; Fuentes, Lajo, Carrión, \& Cuñé, 2013). One strain of L. brevis has been reported to reduce the incidence of influenza in school children (Waki, Matsumoto, Fukui, \& Suganuma, 2014).

The soymilk from different varieties displayed differences in their promotion of the growth of the lactic acid bacteria. For example, growth of $L$. reuteri was significantly higher in the variety LocS than in Peka 6, Saga and LocW $(\mathrm{P}<0.05)$. Further studies are required to test the probiotic properties and health benefits.

$3.2 .2 \mathrm{pH}$

The $\mathrm{pH}$ at time 0 was $6.62 \pm 0.02$. At time $24 \mathrm{~h}$, the mean $\mathrm{pH}$ between strains was significantly different $(\mathrm{P}<0.05)$, Figure 1. 


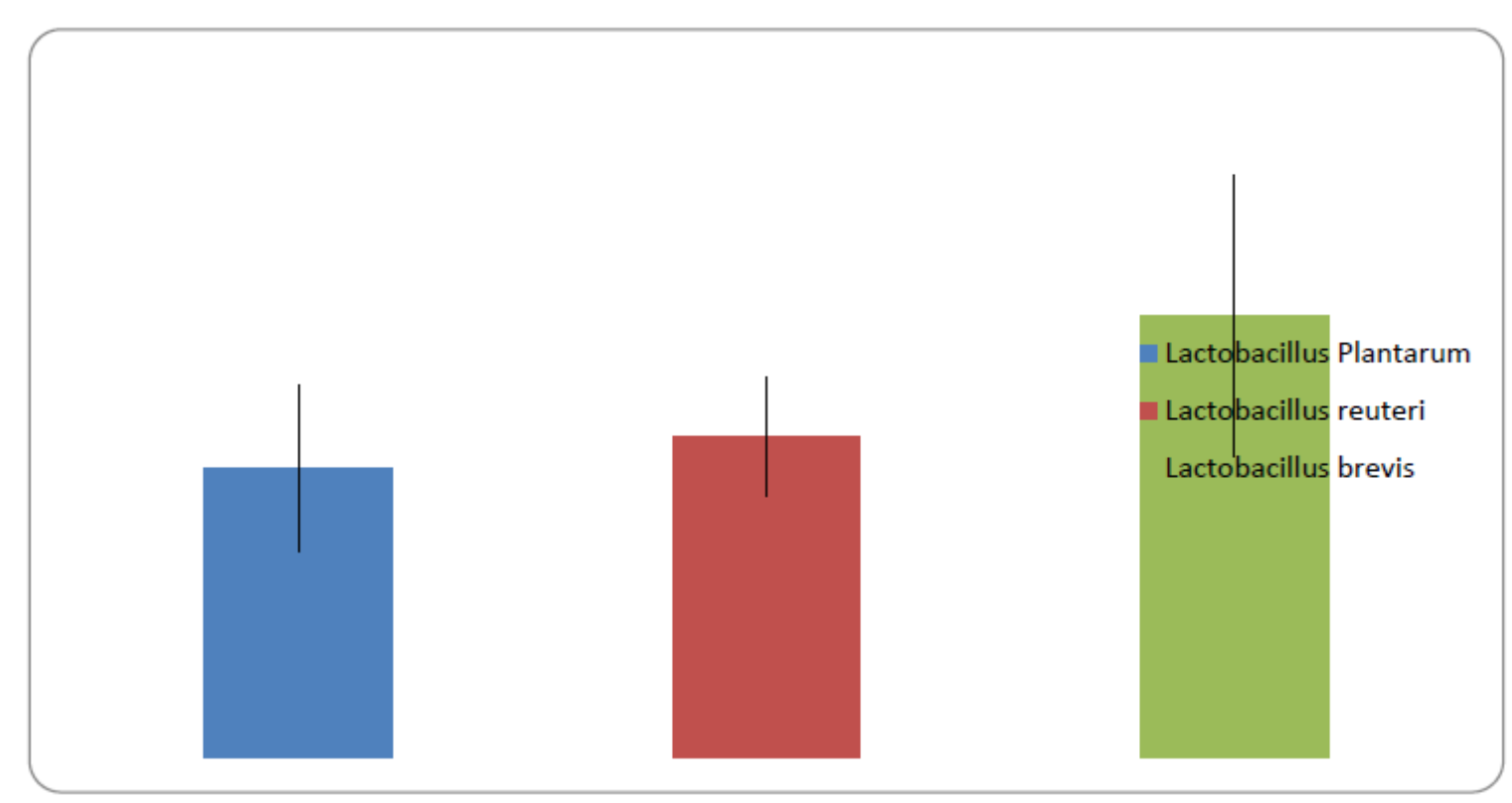

Figure 1. Mean $\mathrm{pH}$ after 24hours of soybean milk fermentation

Fermentation with $L$. plantarum resulted in the most acidic fermented soymilk followed by $L$. reuteri and lastly $L$. brevis.

\subsubsection{Titratable Acidity (TA)}

The TA varied between $2.17 \mathrm{~g} \mathrm{LA} / \mathrm{L}(0.2 \% \mathrm{TA})$ and $4.20 \mathrm{~g} \mathrm{LA} / \mathrm{L}(0.42 \%)$ (Figure 2). This is in the range with values found by Obadina of $0.42 \%$ (Obadina, Akinola, Shittu, \& Bakare, 2013). The difference between strains as well as between varieties was not significant $(\mathrm{P}>0.05)$.

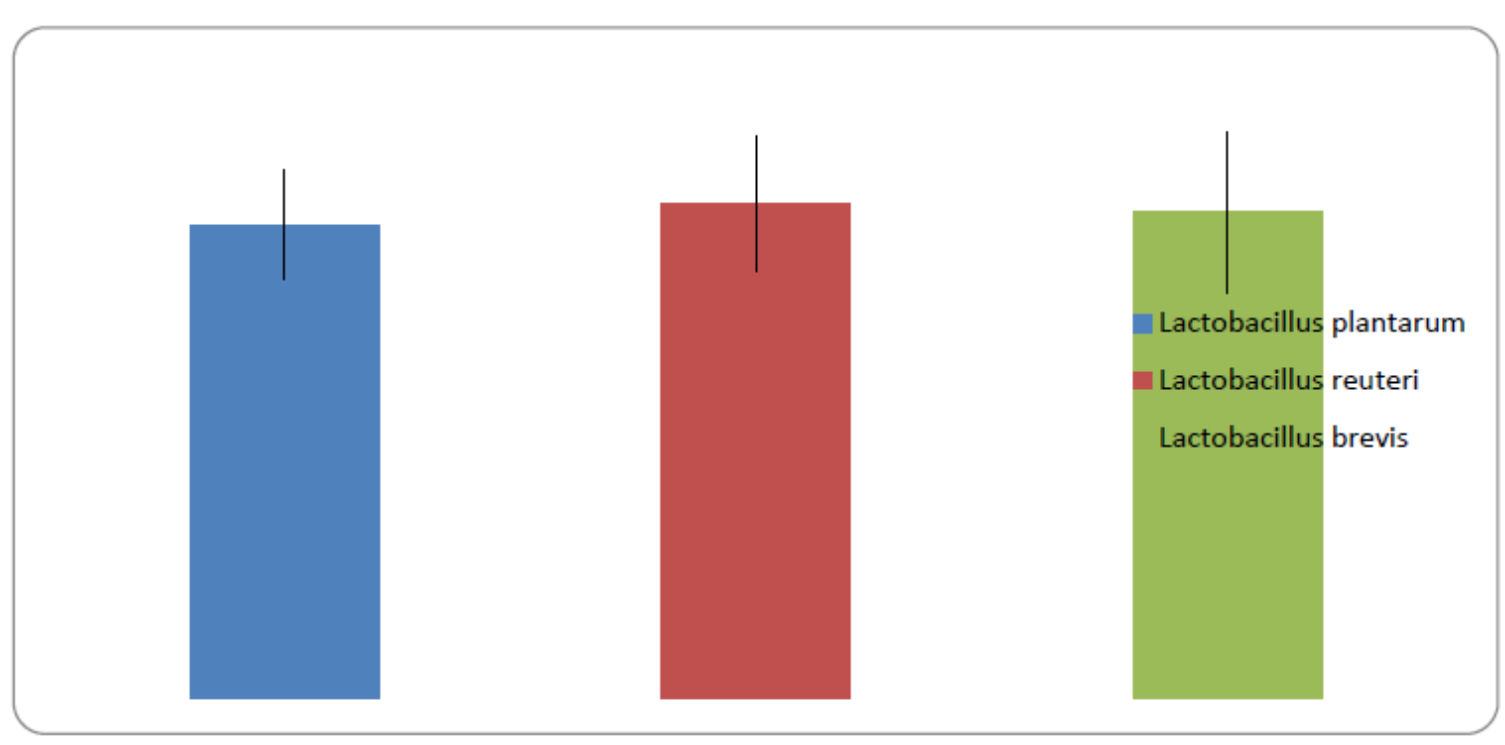

Figure 2. Titratable acidity of fermented soybean milk after 24hours

The development of acidity during fermentation is higher in cow's milk than in soymilk, which takes a long time to ferment as reported in previous study (Ismail, 2016). This was observed in this study as well as where the soybean milk started to coagulate only after 6 hours.

\subsubsection{Total Phenolic Compound Content (TPC) and Antioxidant Activity}

Soybean flour had a mean TPC of $82.65 \mathrm{mg}$ GAE/100g. LocE variety had the highest TPC content as compared 
to other varieties for soymilk, fermented soymilk and soybean flour. Soymilk had a mean TPC of $10.16 \mathrm{mg}$ GAE/100g. The mean TPC for fermented soybean milk was $7.72 \mathrm{mg}$ GAE/100g. There were significant differences in TPC of soymilk made from the different varieties $(\mathrm{P}=0.001)$ but, there were no significant differences between bacterial strains. Fermented soymilk had a slightly higher DPPH scavenging activity $(3.20 \pm 0.12 \mathrm{mg} \mathrm{TE} / 100 \mathrm{~g})$ than non-fermented soymilk (3.08 \pm 0.07$)$. This is consistent with previous reports that fermented soybean products have higher antioxidant activity than unfermented ones (Di Cagno et al., 2010; Riciputi et al., 2016; Yang, Chen, Zhang, Chen, \& Liu, 2012; Yao et al., 2010). Chien et al. (2006) reported that fermented soymilk had lower total isoflavones than non-fermented soymilk but had a high antioxidant activity due to the increase in aglycones during fermentation. $\beta$-Galactosidase transforms glycosides into aglycones (daidzein and genistein) (Malashree et al., 2016; Pyo et al., 2005).

The Trolox equivalent (TE) of soybean flour was $17.20 \pm 0.40 \mathrm{mg}$ TE/100g. The difference in antioxidant activity was not significant between the three bacteria. However, as shown in Figure 3, Saga variety showed a significantly different scavenging activity from SB24 and Peka $6(\mathrm{P}<0.05)$.

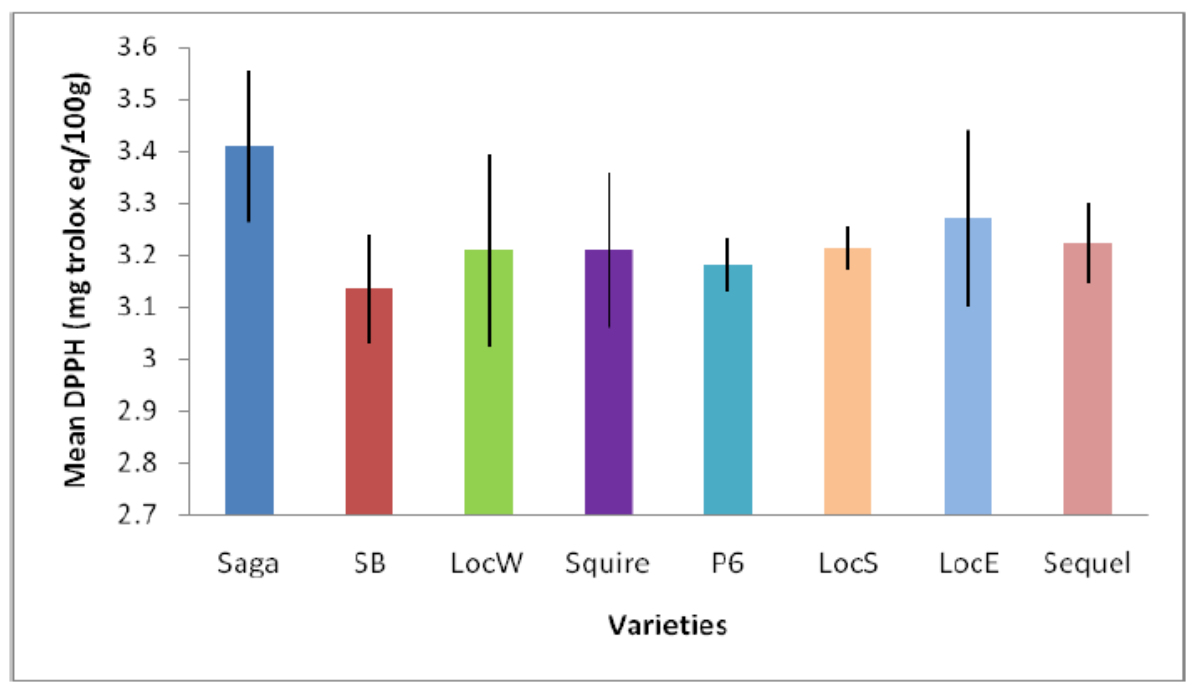

Figure 3. Antioxidant activity of fermented soybean milk by L. reuteri

\subsubsection{Effect of Fermentation on Oligosaccharides}

Concentrations of oligosaccharides in term of $\mathrm{g} / 100 \mathrm{~g}$ raffinose in soy flour (SF), soymilk (SM) and fermented soymilk (FSM) obtained from different soybean varieties are presented in table 3. Varieties like Saga, SB24 and Squire have significantly less oligosaccharides than Peka 6, Sequel and the three local varieties.

Table 3. Concentrations of oligosaccharides in soybean flour (SF), soymilk (SM) and fermented soymilk (FSM)

\begin{tabular}{lllllll}
\hline $\begin{array}{l}\text { Soybean } \\
\text { varieties }\end{array}$ & $\begin{array}{l}\text { Concentration } \\
\text { raffinose SF } \\
(\mathrm{g} / 100 \mathrm{~g})\end{array}$ & SD SF & $\begin{array}{l}\text { Concentration } \\
\text { raffinose SM } \\
(\mathrm{g} / 100 \mathrm{~g})\end{array}$ & $\begin{array}{l}\text { SD } \\
\text { SM }\end{array}$ & $\begin{array}{l}\text { Concentration } \\
\text { raffinose FSM } \\
(\mathrm{g} / 100 \mathrm{~g})\end{array}$ & $\begin{array}{l}\text { SD } \\
\text { FSM }\end{array}$ \\
\hline Saga & 6.67 & 0.24 & 0.47 & 0.01 & 0.41 & 0.02 \\
SB & 6.90 & 0.18 & 0.52 & 0.01 & 0.45 & 0.04 \\
LocW & 6.72 & 0.08 & $0.64^{*}$ & 0.03 & $0.53^{*}$ & 0.01 \\
Squire & 6.34 & 0.10 & 0.52 & 0.02 & 0.47 & 0.01 \\
P6 & $7.55^{*}$ & 0.12 & $0.68^{*}$ & 0.05 & $0.58^{*}$ & 0.02 \\
LocS & $7.73^{*}$ & 0.16 & $0.67^{*}$ & 0.02 & $0.54^{*}$ & 0.08 \\
LocE & 7.11 & 0.18 & $0.67^{*}$ & 0.02 & $0.56^{*}$ & 0.04 \\
Sequel & $7.95^{*}$ & 0.08 & 0.60 & 0.02 & $0.53^{*}$ & 0.02 \\
\hline
\end{tabular}

*Significantly different from others in the same column; $\mathrm{SD}=$ Standard deviation

Upon fermentation of soymilk by L. reuteri, L. brevis and L. plantarum, the concentration of oligosaccharides expressed in term of raffinose $(\mathrm{g} / 100 \mathrm{~g})$ was significantly different by strains and by varieties $\mathrm{P}<0.05$. L . reuteri reduced the most of the oligosaccharides followed by L. brevis (Figure 4). This is consistent with the results that L. reuteri was the fastest growing, followed by L. brevis. 


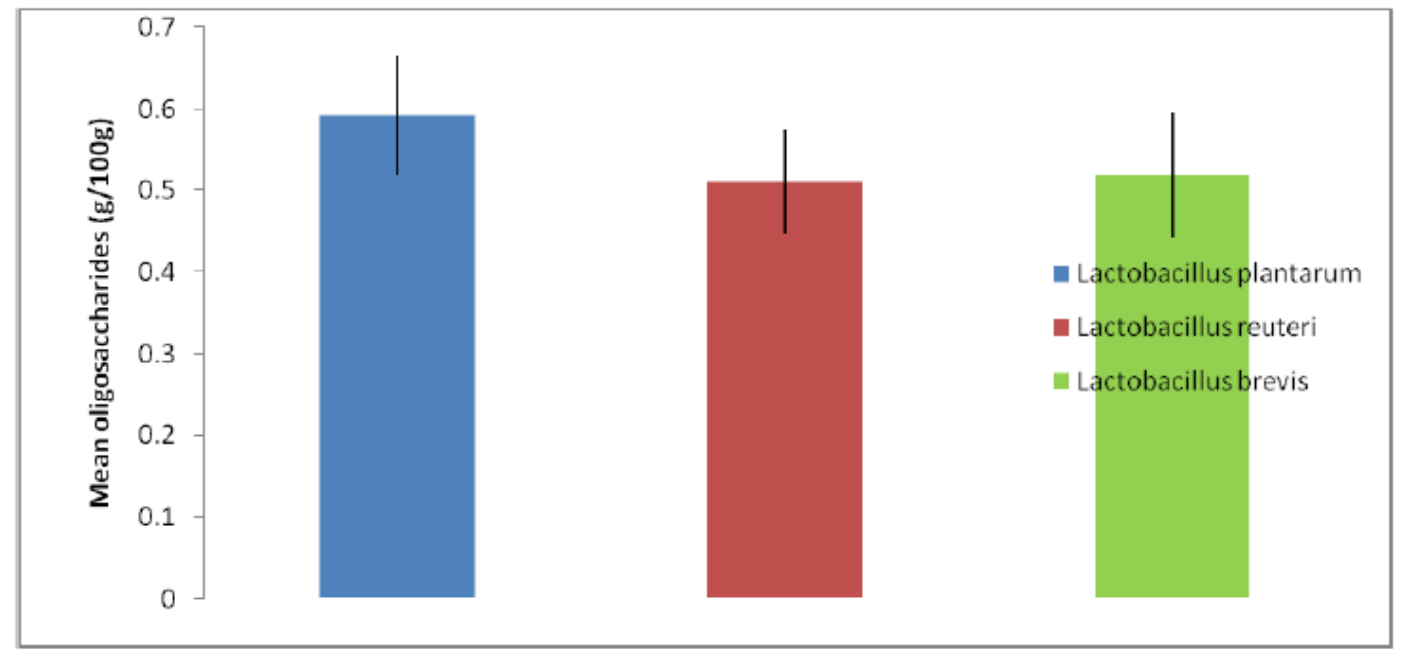

Figure 4. Oligosaccharides content in fermented soybean milk

Fermentation reduces sucrose, raffinose and stachyose(Length, 2011) due to the $\alpha$-galactosidase activity of lactic acid bacteria on oligosaccharides (Donkor et al., 2007). The presence of $\alpha$-D-galactosyl oligosaccharides stimulates the activity of this enzyme (Scalabrini, Rossi, Spettoli, \& Matteuzzi, 1998; Tsangalis \& Shah, 2004). As shown in Table 3, fermentation led to a reduction in oligosaccharide content of the soymilk from different varieties. A paired samples test showed a significant difference between fermented soymilk and non-fermented soymilk $(\mathrm{P}<0.05)$. Fermentation reduces sucrose, raffinose and stachyose(Length, 2011). This is due to the $\alpha$-galactosidase activity of lactic acid bacteria on oligosaccharides metabolism (Donkor et al., 2007). The

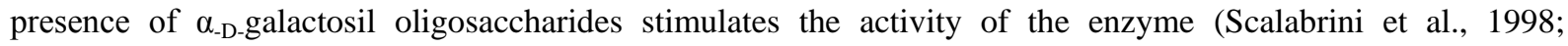
Tsangalis \& Shah, 2004).

\section{Conclusion}

Three probiotic bacteria, namely Lactobacillus reuteri, Lactobacillus brevis and Lactobacillus plantarum grew to attain over $\log 8 \mathrm{CFU} / \mathrm{ml}$ within 24 hours of incubation at $30^{\circ} \mathrm{C}$. This coincided with a reduction of $\mathrm{pH}$ and increase in viscosity characteristics of a good fermented product. Thus, these bacteria can be used in the production of probiotic soymilk. Fermentation also caused an increase in soymilk antioxidant activity and decrease in causing flatulence oligosaccharides, which translates into health benefits of fermented soybean products.

\section{Acknowledgement}

This project was funded by the African Women in Agriculture Research and Development (AWARD) through Advanced Science Training as PhD exchange student at Ghent University, Belgium. The support from the Rwanda Agriculture Board (RAB), Jomo Kenyatta University of Agriculture and Technology (JKUAT), Kenya and Ghent University, Belgium is highly appreciated.

\section{References}

Amutha, K., \& Kokila, V. (2015). Cholesterol Lowering Property of Lactobacillus Plantarum Isolated from Cow Milk.International Journal of Pharmaceutical Sciences and Research, 6(3), 1184-1189. https://doi.org/10.13040/IJPSR.0975-8232.6(3).1184-89

Bansal, S., Mangal, M., Sharma, S. K., Yadav, D. N., \& Gupta, R. K. (2015). Optimization of Fermentation Conditions for Probiotic Soy Yoghurt Using Response Surface Methodology.Journal of Food Processing and Preservation, 39(6), 1809-1816. https://doi.org/10.1111/jfpp.12415

Battistini, C., Gullón, B., Ichimura, E. S., Gomes, A. M. P., Ribeiro, E. P., Kunigk, L., ... Jurkiewicz, C. (2018). Development and characterization of an innovative synbiotic fermented beverage based on vegetable soybean. Brazilian Journal of Microbiology, 49(2), 303-309. https://doi.org/10.1016/j.bjm.2017.08.006

Breed, R. S., Murray, E. G. D., \& Hitchens, A. P. (1948). Bergey's manual of determinative bacteriology (Sixth edition). Baltimore, Md., U. S. A.: The Williams \& Wilkins company.

Champagne, C. P., Raymond, Y., Guertin, N., Martoni, C. J., \& Jones, M. L. (2016). Growth of Lactobacillus 
reuteri NCIMB 30242 during yogurt fermentation and bile salt hydrolysis activity in the product. Dairy Science \& Technology,96, 173-184.

Cheng, I.-C. (2005). Effect of fermented soy milk on the intestinal bacterial ecosystem. World Journal of Gastroenterology, 11(8), 1225. https://doi.org/10.3748/wjg.v11.i8.1225

Cheng, Y. J., Thompson, L. D., \& Brittin, H. C. (1990). Sogurt, a Yogurt-like Soybean Product: Development and Properties. Journal of Food Science, 55(4), 1178-1179. https://doi.org/10.1111/j.1365-2621.1990.tb01631.x

Chien, H., Yang, T., \& Chou, C. (2013). Effects of Storage Conditions on the Stability of Isoflavone Isomers in Lactic Fermented Soymilk Powder. Food Bioprocess Technol, 6, 1059-1066. https://doi.org/10.1007/s11947-012-0792-y

Di Cagno, R., Mazzacane, F., Rizzello, C. G., Vincentini, O., Silano, M., Giuliani, G., ... Gobbetti, M. (2010). Synthesis of isoflavone aglycones and equol in soy milks fermented by food-related lactic acid bacteria and their effect on human intestinal caco-2 cells. Journal of Agricultural and Food Chemistry, 58(19), 10338-10346. https://doi.org/10.1021/jf101513r

Donkor, O. N., Henriksson, A., Vasiljevic, T., \& Shah, N. P. (2007). a -Galactosidase and proteolytic activities of selected probiotic and dairy cultures in fermented soymilk. Food Chemistry, 104(1), 10-20. https://doi.org/10.1016/j.foodchem.2006.10.065

Fuentes, M., Lajo, T., Carrión, J., \& Cuñé, J. (2013). Cholesterol-lowering efficacy of Lactobacillus plantarum CECT 7527, 7528 and 7529 in hypercholesterolaemic adults.British Journal of Nutrition, 109(10), 1866-1872. https://doi.org/10.1017/S000711451200373X

Gandhi, A. P. (2009). Review paper quality of soybean and its food products. International Food Research Journal, 16(1), 11-19.

Garro, M. S., de Valdez, G. F., \& de Giori, G. S. (2004). Temperature effect on the biological activity of Bifidobacterium longum CRL 849 and Lactobacillus fermentum CRL 251 in pure and mixed cultures grown in soymilk. Food Microbiology, 21(5), 511-518. https://doi.org/10.1016/j.fm.2004.01.001

Gote, M., Umalkar, H., Khan, I., \& Khire, J. (2004). Thermostable $\alpha$-galactosidase from Bacillus stearothermophilus (NCIM 5146) and its application in the removal of flatulence causing factors from soymilk. Process Biochemistry, 39(11), 1723-1729. https://doi.org/10.1016/j.procbio.2003.07.008

Horackova, S., Muhlhansova, A., Slukova, M., Schulzova, V., \& Plockova, M. (2015). Fermentation of Soymilk by Yoghurt and Bifidobacteria Strains. Czech Journal of Food Sciences, 33(4), 313-319. https://doi.org/10.17221/115/2015-CJFS

Hosken, B. (2000). Advances in soybean processing and utilisation. University of Newcastle, method reviewed by Lui, KeShun. Soybeans: Chemistry, Technology and Utilisation, Aspen Pub Inc. Maryland.

Ismail, M. M. (2016). Chemical Composition, Sensory Evaluation and Starter Activity in Cow, Soy, Peanut and Rice Milk. Journal of Nutritional Health \& Food Engineering, 5(3). https://doi.org/10.15406/jnhfe.2016.05.00175

Jooyandeh, H. (2011). Soy Products as Healthy and Functional Foods, MEJSR,7(1), 71-80.

Kaczmarska, K. T., Chandra-Hioe, M. V., Zabaras, D., Frank, D., \& Arcot, J. (2017). Effect of Germination and Fermentation on Carbohydrate Composition of Australian Sweet Lupin and Soybean Seeds and Flours. Journal of Agricultural and Food Chemistry, 65(46), 10064-10073. https://doi.org/10.1021/acs.jafc.7b02986

Khaleque, A., Bannatyne, W. R., \& Wallace, G. M. (1970). Studies on the processing and properties of soymilk I.-Effect of preprocessing conditions on the flavour and compositions of soymilks. Journal of the Science of Food and Agriculture, 21(11), 579-583. https://doi.org/10.1002/jsfa.2740211110

Kumaran, A., \& Karunakaran, R. (2006). Antioxidant and free radical scavenging activity of an aqueous extract of Coleus aromaticus, 97(1), 109-114. https://doi.org/10.1016/j.foodchem.2005.03.032

Kumari, S., Dahuja, A., Vinutha, T., Lal, S. K., Kar, A., \& Rai, R. D. (2015). Changes in the Levels of Off-Flavor Generation in Soybean through Biotic Elicitor Treatments. Journal of Agricultural and Food Chemistry, 63(2), 700-706. https://doi.org/10.1021/j5505199a

Length, F. (2011). Effect of oligosaccharides and isoflavones aglycones in defatted soy meal fermented by 
Lactobacillus paracasei and Bifidobacterium longum. African Journal of Microbiology Research, 5(15), 2011-2018. https://doi.org/10.5897/AJMR10.553

Li, H., Yan, L., Wang, J., \& Zhang, Q. (2012). Fermentation characteristics of six probiotic strains in soymilk. Ann Microbiol, 62, 1473-1483. https://doi.org/10.1007/s13213-011-0401-8

Liu, W.-S., Yang, C.-Y., \& Fang, T. J. (2018). Strategic ultrasound-induced stress response of lactic acid bacteria on enhancement of $\beta$-glucosidase activity for bioconversion of isoflavones in soymilk. Journal of Microbiological Methods, 148, 145-150. https://doi.org/10.1016/j.mimet.2018.04.006

Malashree, L., Mudgil, P., Dagar, S. S., Kumar, S., Kumar, A., Malashree, L., ... Kumar, S. (2016). $\beta$ -Glucosidase Activity of Lactobacilli for Biotransformation of Soy Isoflavones $\beta$-Glucosidase Activity of Lactobacilli for Biotransformation. Food Biotechnology, 5436(December), 154-163. https://doi.org/10.1080/08905436.2012.670832

Marazza, A., Nazareno, A., Savoy, G., Giori, D., \& Garro, M. S. (2012). Enhancement of the antioxidant capacity of soymilk by fermentation with Lactobacillus rhamnosus. Journal of Functional Foods, 4, 0-7. https://doi.org/10.1016/j.jff.2012.03.005

Min, S., Yu, Y., Yoo, S., \& Martin, S. S. (2005). Effect of Soybean Varieties and Growing Locations on the Flavor of Soymilk. Journal of Food Science, 70(1), C1-C11. https://doi.org/10.1111/j.1365-2621.2005.tb09009.x

Mishra, S., \& Mishra, H. N. (2013). Effect of Synbiotic Interaction of Fructooligosaccharide and Probiotics on the Acidification Profile, Textural and Rheological Characteristics of Fermented Soy Milk. Food Bioprocess Technol, 6, 3166-3176. https://doi.org/10.1007/s11947-012-1021-4

Molina, V., Medici, M., Font De Valdez, G., \& Taranto, M. P. (2012). Soybean-based functional food with vitamin B 12 -producing lactic acid bacteria. Journal of Functional Foods, 4, 4-9. https://doi.org/10.1016/j.jff.2012.05.011

Mudryj, A. N., Aukema, H. M., \& Yu, N. (2015). Intake patterns and dietary associations of soya protein consumption in adults and children in the Canadian Community Health Survey, Cycle 2.2. British Journal of Nutrition, 113(02), 299-309. https://doi.org/10.1017/S0007114514003638

Niyibituronsa, M., Onyango, A. N., Gaidashova, S., Imathiu, S., Uwizerwa, M., Ochieng, E. P., ... Harvey, J. (2018). The effect of different processing methods on nutrient and isoflavone content of soymilk obtained from six varieties of soybean grown in Rwanda. Food Science \& Nutrition. https://doi.org/10.1002/fsn3.812

Obadina, A. O., Akinola, O. J., Shittu, T. A., \& Bakare, H. A. (2013). Effect of Natural Fermentation on the Chemical and Nutritional Composition of Fermented Soymilk Nono. Nigerian Food Journal, 31(2), 91-97. https://doi.org/10.1016/S0189-7241(15)30081-3

Otieno, D. O., Ashton, J. F., \& Shah, N. E. (2006). Stability of $\beta$-glucosidase Activity Produced by Bifidobacterium and Lactobacillus spp. in Fermented Soymilk During Processing and Storage. Journal of Food Science, 70(4), M236-M241. https://doi.org/10.1111/j.1365-2621.2005.tb07194.x

Peng, X., \& Guo, S. (2015). Texture characteristics of soymilk gels formed by lactic fermentation: A comparison of soymilk prepared by blanching soybeans under different temperatures. Food Hydrocolloids, 43, 58-65. https://doi.org/10.1016/j.foodhyd.2014.04.034

Riciputi, Y., Serrazanetti, D. I., Verardo, V., Vannini, L., Caboni, M. F., \& Lanciotti, R. (2016). Effect of fermentation on the content of bioactive compounds in tofu-type products. Journal of Functional Foods, 27, 131-139. https://doi.org/10.1016/j.jff.2016.08.041

Scalabrini, P., Rossi, M., Spettoli, P., \& Matteuzzi, D. (1998). Characterization of Bifidobacterium strains for use in soymilk fermentation. International Journal of Food Microbiology, 39(3), 213-219. https://doi.org/10.1016/S0168-1605(98)00005-1

Shumoy, H., Gabaza, M., Vandevelde, J., \& Raes, K. (2017). Soluble and bound phenolic contents and antioxidant capacity of tef injera as affected by traditional fermentation. Journal of Food Composition and Analysis, 58, 52-59. https://doi.org/10.1016/j.jfca.2017.01.004

Shurtleff, W., \& Aoyagi, A. (2004). History of Fermented Soymilk and Its Products. In History of Soybeans and Soyfoods, 1100 B.C. to the 1980s. Lafayette, California: Soyinfo Center. Retrieved from http://www.soyinfocenter.com/HSS/fermented_soymilk.php

Singleton, V. L., Orthofer, R., \& Lamuela-Raventós, R. M. (1999). Analysis of total phenols and other oxidation 
substrates and antioxidants by means of folin-ciocalteu reagent. Methods in Enzymology,299, 152-178. https://doi.org/10.1016/S0076-6879(99)99017-1

Takagi, A., Kano, M., \& Kaga, C. (2015). Possibility of Breast Cancer Prevention: Use of Soy Isoflavones and Fermented Soy Beverage Produced Using Probiotics. International Journal of Molecular Sciences, 16(12), 10907-10920. https://doi.org/10.3390/ijms160510907

Telang, A. M., Joshi, V. S., Sutar, N., \& Thorat, B. N. (2010). Enhancement of Biological Properties of Soymilk by Fermentation. Food Biotechnology, 24(4), 375-387. https://doi.org/10.1080/08905436.2010.524489

Tsangalis, D., Ashton, J. F., Stojanovska, L., Wilcox, G., \& Shah, N. P. (2004). Development of an isoflavone aglycone-enriched soymilk using soy germ, soy protein isolate and bifidobacteria. Food Research International, 37(4), 301-312. https://doi.org/10.1016/j.foodres.2004.01.003

Tsangalis, D., \& Shah, N. P. (2004). Metabolism of oligosaccharides and aldehydes and production of organic acids in soymilk by probiotic bifidobacteria. International Journal of Food Science and Technology, 39(5), 541-554. https://doi.org/10.1111/j.1365-2621.2004.00814.x

Vij, S., Hati, S., \& Yadav, D. (2011). Biofunctionality of Probiotic Soy Yoghurt. Food and Nutrition Sciences, 02(05), 502-509. https://doi.org/10.4236/fns.2011.25073

Villares, A., Rostagno, M. A., García-Lafuente, A., Guillamón, E., \& Martínez, J. A. (2011). Content and Profile of Isoflavones in Soy-Based Foods as a Function of the Production Process. Food and Bioprocess Technology, 4(1), 27-38. https://doi.org/10.1007/s11947-009-0311-y

Waki, N., Matsumoto, M., Fukui, Y., \& Suganuma, H. (2014). Effects of probiotic Lactobacillus brevis KB290 on incidence of influenza infection among schoolchildren: an open-label pilot study. Letters in Applied Microbiology, 59(6), 565-571. https://doi.org/10.1111/lam.12340

Wang, H. L., Kraidej, L., \& Hesseltine, C. W. (1974). LACTIC ACID FERMENTATION OF SOYBEAN MILK. Journal of Milk and Food Technology, 2(2), 71-73.

Yang, X., Chen, J., Zhang, C., Chen, H., \& Liu, Y. (2012). Evaluation of antioxidant activity of fermented soybean meal extract. African Journal of Pharmacy and Pharmacology, 6(24), 1774-1781. https://doi.org/10.5897/AJPP12.392

Yao, Q., Xiao-Nan, J., \& Dong, P. H. (2010). Comparison of Antioxidant Activities in Black Soybean Preparations Fermented with Various Microorganisms, 9(7), 1065-1071.

Yu, H., Liu, R., Hu, Y., \& Xu, B. (2017). Flavor profiles of soymilk processed with four different processing technologies and 26 soybean cultivars grown in China. International Journal of Food Properties, 20(sup3), S2887-S2898. https://doi.org/10.1080/10942912.2017.1382507

Ziaei, S., \& Halaby, R. (2017). Dietary Isoflavones and Breast Cancer Risk. Medicines, 4(2), 18. https://doi.org/10.3390/medicines4020018

\section{Copyrights}

Copyright for this articleis retained by the author(s), with first publication rights granted to the journal.

This is an open-access article distributed under the terms and conditions of the CreativeCommons Attribution license (http://creativecommons.org/licenses/by/4.0/). 